\title{
THE RELATIONSHIP BETWEEN ECONOMIC GROWTH AND ENVIRONMENTAL POLLUTION IN TURKEY
}

\author{
Mohammed ALNOUR*
}

\begin{abstract}
This study examines the relationship between economic growth and environmental pollution in Turkey. The research uses annual time series data from 1970 to 2017. Augmented Dickey-Fuller (ADF) and Phillips-Perron (PP) unit root tests were used to test the stationarity of the series. In this the Autoregressive Distributed Lag (ARDL) model is used as an estimation technique. Furthermore, the classical additive decomposition method was used to forecast the pollution. The results indicate that economic growth has a positive significant effect on environmental pollution in the short-run and positive but insignificant effect in the long-run. When the long-run and short-run elasticities were compared it is found that the long-run elasticity is greater than the short-run elasticity which challenges the validity of the Environmental Kuznets Curve (EKC) hypothesis and provides evidence against its existence in Turkey. The paper suggests that robust and effective environmental policies should be strictly implemented and closely monitored to reduce the environmental pollution and to ensure the preservation of resources for future generations.
\end{abstract}

Keywords: Economic Growth, EKC, Environmental Pollution, $\mathrm{CO}_{2}$, and EFP.

* PhD student, Erciyes University, Institute of Social Sciences, Department of Economics, mohamedmershing88@gmail.com, https://orcid.org/0000-0003-3276-7380. 


\title{
TÜRKIYYE'DE EKONOMIKK BÜYÜME ILE ÇEVRE KİRLILIIĞİ ARASINDAKİ İLIŞKI
}

\begin{abstract}
ÖZ
$\mathrm{Bu}$ çalışma, Türkiye'de ekonomik büyüme ile çevre kirliliği arasındaki ilişkiyi araştırmaktadır. Araştırmada, $1970-2017$ arasındaki yıllık zaman serisi verileri kullanılmıştır. Augmented Dickey-Fuller (ADF) ve Phillips-Perron (PP) birim kök testleri kullanılmıştır. Bu ARDL yaklaşımı bir tahmin tekniği olarak kullanılmaktadır. Ayrıca, kirliliği tahmin etmek için klasik katkı ayrıştırma yöntemi kullanılmıştır. Elde edilenbulgulara göre, ekonomik büyümenin kısa vadede çevre kirliliğine olumlu, uzun vadede ise olumlu önemsiz etkiye sahip olduğunu göstermektedir. Uzun vadeli ve kısa vadeli esneklikler karşılaştırıldığında, uzun vadeli esnekliğin, EKC hipoteziningeçerliliğini desteklemeyen kısa vadeli esneklikten daha büyük olduğu bulunmuştur ve Türkiye'de Çevresel Kuznets Eğrisi hipotezinin varlığına karşı kanıt sağlanmaktadır. Çalışma, çevre kirliliğini azaltmak ve gelecek nesillere aktarılacak kaynakların korunmasını sağlamak için sağlam ve etkili çevre politikalarının sıkı bir şekilde uygulanması ve yakından takip edilmesi gerektiğini öne sürmektedir.
\end{abstract}

Anahtar Kelimeler: Ekonomik Büyüme, EKC, Çevre Kirliliği, CO2 ve EFP.

\section{INTRODUCTION}

The primary goal of economic activities is to increase human welfare and rapid economic growth is seen as a way to reach this goal. However, when production increases the use of resources while the relative cost of production factors diminishes, wastes generated by the production and consumption process increase the environmental cost. As long as economic growth occurs, the use of natural resources will exceed production capacity, leading to an increase in the amount of waste and Greenhouse gas emissions (Pata, 2018). As a result of increasing economic activities and the exploitation of natural resources, the size of the Greenhouse gas emissions has reached serious levels. The world's countries emit vastly different amounts of heat-trapping gases into the atmosphere. The figure (2) below shows data provided by the International Energy Agency, which estimates carbon dioxide $\left(\mathrm{CO}_{2}\right)$ emissions from the combustion of coal, natural gas, oil, and other fuels, including industrial waste and non-renewable municipal waste and rubbish.

International organizations, such as the United Nations, have been constantly attempting to reduce the adverse impacts of global warming and climate changes through intergovernmental and binding agreements, such as Paris Agreement. The Paris Agreement is an agreement within the United Nations Framework Convention on Climate Change mitigation, adaptation, and finance, signed in 2016. It sets out a global framework to avoid dangerous climate change by limiting global warming to well below $2^{\circ} \mathrm{C}$ and pursuing efforts to limit it to $1.5^{\circ} \mathrm{C}$. It also aims to promote countries' ability to deal with 
the impacts of climate change and support them in their efforts (United Nations). Turkey has experienced a significant rise in energy consumption and carbon emissions alongside the economic growth in recent decades, the $\mathrm{CO}_{2}$ emissions is constantly increasing along the growth trajectory. According to the International Energy Agency (IEA); Turkey is among the 20 countries that emitted the most carbon dioxide in 2018, Turkey's share in carbon emissions is $1 \%$ of the total world's emissions. In its eleventh development plan (2019-2023), Turkey aims to protect the environment and natural resources, improve quality, ensure effective, integrated, and sustainable management, implement environment and climate-friendly practices in all areas, and increase environmental awareness and sensitivity of all segments of the society. In addition, and within the scope of national conditions, climate change will be tackled in sectors causing Greenhouse gas emissions and the resilience of the economy and society to climate risks will be increased by capacity building for adaptation to climate change (see, Eleventh Development Plan, 2019-2023).

Furthermore, Turkey is a candidate to become a member of the European Union (EU) and will likely face significant pressures from EU during negotiations to introduce its national plan on climate change and global warming along with specific emission targets and the related abatement policies (Ozturk and Acaravci, 2010). For these reasons, investigating the relationship between economic growth and environmental degradation in Turkey is very important and will significantly contribute in designing environmental management policies and their implementation.

In the light of the importance of addressing environmental issues a large number of studies have examined the relationship between economic growth and environmental deterioration under the Environmental Kuznets Hypothesis framework (Lachehebet al., 2015; Bölük and Mert, 2015; Ali et al., 2017; Salahuddin et al., 2016; Awad, 2019). However, an important weakness of many studies that investigated the Environmental Kuznets Curve is that carbon dioxide $\left(\mathrm{CO}_{2}\right)$ was used as an indicator for environmental deterioration while it contributes only partially to total environmental damage (Uddin et al., 2017).

This research will depart from previous studies and use the ecological footprint as well as cordon dioxide $(\mathrm{CO} 2)$ as measures of environmental pollution. The ecological footprint is an aggregate measure of the environment. It consists of six components of surface productive areas: carbon footprint, fishing ground, build-up, forest land, cropland, and grazing land (Solarin and Bello, 2018). The study covers a relatively large sample spanning the period 1970 - 2017. The Environmental Kuznets Hypothesis (EKC) will be examined using the Autoregressive Distributed Lag (ARDL) model suggested by Pesaran et al., (2001).

The rest of the paper is organized as follows: Section two reviews important literature on the subject. Section three presents the methodology. 
Section four shows the results and discussion while section five provides the conclusion.

\section{THEORETICAL FRAMEWORK}

Human beings are presently confronted by two major challenges; economic growth and preserving the environment (Uddin et al., 2017). When the economy starts moving along the growth trajectory then at the earliest stage of the economic growth environment deteriorate due to air pollution, deforestation, and many other pollutants. With an increase in per capita income economy starts to develop and environmental deterioration declines (Shahbaz and Sinha, 2018). This association between economic growth and environmental degradation is hypothesized to be an inverted U-shaped relationship and is referred to in the literature as the Environmental Kuznets Curve (EKC). The EKC hypothesis was firstly introduced by Simon Kuznets (1956) and later confirmed by Grossman and Krueger (1995).

Figure 1 explains the Environmental Kuznets Curve. It indicates that at the early stage of the development process economic growth tends to increase Greenhouse gas emissions and as a result contributes to global warming and climate change, and when economic growth passes a certain point, it reduces the Greenhouse gas and hence improves the quality of the environment (Sirag et al., 2018).

Figure 1. Environmental Kuznets Curve

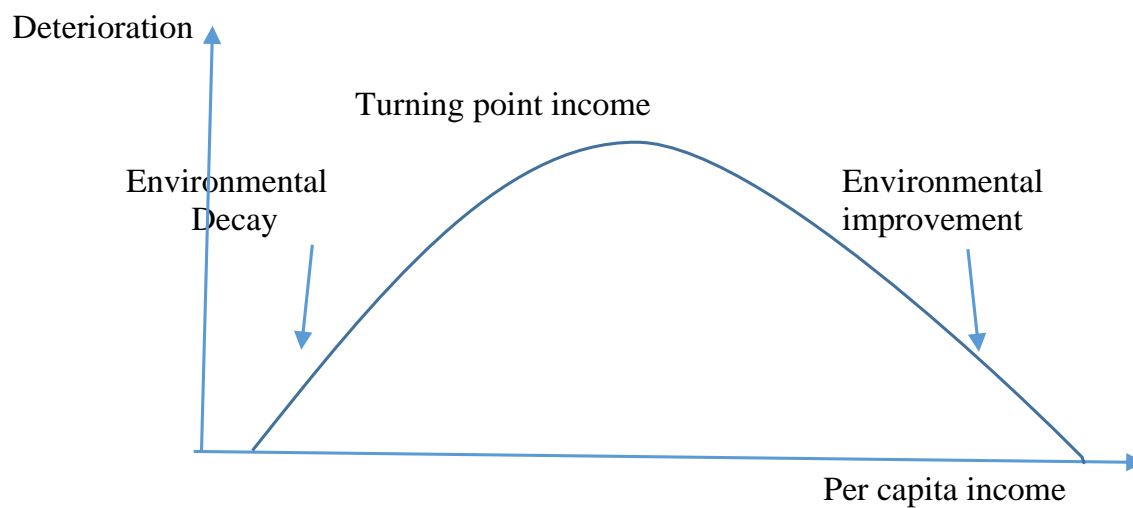

Source: graphed by the author

As environmental degradation has become more severe, the relationship between environmental degradation and economic growth becomes an increasingly important issue (Tutulmaz, 2015). According to the Environmental Kuznets Curve hypothesis, economic growth is both cause of and solution to environmental deterioration. Therefore, investigating the validity of the EKC hypothesis becomes prominent to economic growth and environmental policies 
(Acaravci and Akalin, 2017). Although the relationship between economic growth and environmental degradation is extensively investigated in literature, however, (Stern, 2004) argued that the issues of the EKC should be revisited by using new models and decompositions with different panels and time series data sets. Moreover, there are some researchers believe that the Environmental Kuznets Curve is caused by upgrading from the adjustment of economic structures (Tiwari et al., 2013).

Some authors (see for instance, Grossman and Krueger, 1991; Stern, 2004; Song et al., 2008) have emphasized the role of three different effects in Environmental Kuznets Curve: First; the scale effect; it means that using more natural resources in the production process leads to the destruction of nature while technology is constant, which is defined as environmental deterioration. Second, the structural effect; it means that economic development passes through stages starting from the preliminary upgrade, from an agriculture system to the rapid development of high-grade, industrial structures with high-pollution industries and then finally turns to more information-concentrated industries, which leads to improvements in environmental quality. Third, the technique effect; it means that economic growth can break through one threshold point after arriving at a certain stage of economic development. Hence, at a lowincome level, only the high pollution technique can be used but, after crossing the threshold point of economic development, cleaner technologies can be adopted which lowers the deterioration in environmental quality.

Lopez and Islam, (2008) on the other hand, used the income elasticity of demand for environmental quality to explain the EKC. He argued that the demand for a clean environment increases while real income per capita increases. This approach was further explained by (Lieb, 2002), who argued that an increase in income improves the level of education, and this creates awareness about the environment. Moreover, an increase in income distribution has positive effects on the environment.

\section{LITERATURE REVIEW}

The relationship between economic growth and environmental quality is one of the most controversial issues in many fields of science because of climate change and global warming problems (Aslan et al., 2018). The issue of the relationship between the environment and development has attracted the attention of researchers for many decades. Over the years, studies have tried to figure out the determinants of environmental pollution (Ali et al., 2016). There is a wide belief that the environment deteriorates at the early stage of development and improves as per capita income increases. In 1956 Simon Kuznets speculated that the relationship between economic growth and environmental deterioration predicts an inverted U-shaped. 
Several empirical studies (see for instance, Al-Mulaliet al., 2015; Diaoet al., 2009; Ibrahim and Law, 2016; Lachehebet al., 2015; Ben Jebliet al., 2015; Ali et al., 2016; Moutinhoet al., 2017; Adu, and Dekyriah, 2017; Katircioğlu and Taşpinar, 2017; Özokcu and Özdemirb, 2017; Siraget al., 2018; Awad, 2019; Raza et al., 2020) have tested the EKC hypothesis using different techniques of analysis and estimation methods. However, the findings are mixed and inconclusive. For instance, Özokcu and Özdemir (2017), found an N-shaped relationship when testing the EKC hypothesis in OECD countries. Lacheheb et al., (2015) found no evidence for the relationship when investigating the Environmental Kuznets Curve hypothesis in Algeria while Sirag et al., (2018) have found an evidence supporting the existence of EKC in developed countries.

Jalil and Mahmud (2009) concluded that the EKC hypothesis is valid when utilized the ARDL bound test to probe income-pollution relationship for China for the period 1975-2005.Akbostanc1 et al. (2009) applied both time series and panel data series methods to examine whether the inverted U-shaped relationship between economic growth and environmental degradation exists or not for Turkey, but he found no evidence supporting the validity of EKC hypothesis in Turkey.

He and Richard (2010) also found no evidence supporting the existence of the EKC hypothesis when they examined the relationship between GDP per capita and carbon dioxide emissions for Canada for 57 years, and concluded that there is monotonically increasing relationship between income and pollution in Canada. But Iwata et al. (2010) analyzed the existence of the relationship between per capita GDP and carbon emissions in France. This study provides evidence for inverted U-shaped relationship between GDP per capita and CO2 emissions in France. Shahbaz et al. (2014) probed the economic growth-CO2 emissions relationship for Tunisia for 1971-2010 periods. ARDL bound test results show that the EKC hypothesis is valid.

Apergis (2016) used the second-generation panel data methods to test the validity of EKC hypothesis in 15 countries for the period of 1960-2013 and found the evidence that supporting the inverted U-shaped relationship between real income and $\mathrm{CO}_{2}$ emission. CANBAY (2019) used the Autoregressive Distributed Lag Model (ARDL) to examine the effects of economic growth and renewable energy consumption on environmental pollution in Turkey for the period of 1990-2016. He concluded that economic growth increased carbon dioxide $(\mathrm{CO} 2)$ emissions in both the short and the long term while renewable energy consumption reduced $\mathrm{CO}_{2}$ emissions both in the short and long term. Saboori et al. (2016) analyzed the effects of economic growth on environmental pollution for Malaysia spanning period 1980-2008 by utilizing ARDL bound test. The existence of the EKC hypothesis is proved. Li et al. (2016) confirmed the EKC hypothesis when applying panel data method to investigate the link 
between income and pollution indicators $\left(\mathrm{CO}_{2}\right.$, wastewater, and waste solid emissions) for 28 provinces of China spanning the period 1996-2012.

An important limitation of previous studies is that carbon dioxide $\left(\mathrm{CO}_{2}\right)$ was used as the proxy for environmental deterioration. This measure, however, relates only to air pollution and excludes other pollutants impacting on soil, forests, and other environmental aspects. Therefore, the use of carbon dioxide as a proxy for environmental degradation appears to be inadequate measure argument suggests the inadequate. To have a better understanding of the relationship between economic growth and environmental deterioration this research utilizes the ecological footprint (EFP) as well as the carbon dioxide $\left(\mathrm{CO}_{2}\right)$ as measures of environmental pollution.

Recently, a large number of studies have examined the EKC hypothesis using the EFP as a measure of environmental pollution (Ulucak and Lin, 2017; Uddin et al., 2017; Charfeddine and Mrabet, 2017; Ulucak and Bilgili, 2018; Yilanci and Ozgur, 2019; Dogan et al., 2020; Altıntaş and Kassouri, 2020). Ecological footprint is widely used as an index of sustainability. The ecological footprint is a measure of the resources necessary to produce the goods that an individual or population consumes (Fiala, 2008).

Some authors have recognized some of the methodological weaknesses of previous studies (see, for example, Sirag et al., 2018). For example, the GDP and its quadratic term have been used to test the EKC hypothesis, (see, for example Furuoka, 2015; Shahbazet al., 2015; Lachehebet al., 2015; Ibrahim and Law 2014, 2016; Al-Mulaliet al., 2016; Rafindad, 2016; Awad, 2019). This specification makes econometric models vulnerable to multicollinearity and misspecification. Therefore, this research will try to avoid these drawbacks by using the approach of Narayan and Narayan (2010) which involves comparing the short-run and long-run elasticities of per capita income (GDP).

Among the 20 countries that emitted the most carbon dioxide in 2020, Turkey is number sixteen. The share of Turkey in carbon emissions is $1 \%$ of the total world's emissions, it emitted around0.42GT. Turkey aims to tackle the issue of climate change and to decrease the Greenhouse gas emissions within the scope of eleventh development plan (2019-2023) to protect the environment. Therefore, is extremely important to investigate the relationship between the economic growth and environmental deterioration for Turkey.

In this regard, many studies have examined the relationship between economic growth and environmental degradation in Turkey, (see for instance, Altinayet al., 2004; Erdal et al., 2008; Halicioglu,2009; Jobert, and Karanfil, 2007; Lise, and Van Montfort, 2007; Lise,2005;Canbay, 2019; Say and Yücel, 2006; Soytas, 2001; Soytas and Sari, 2009; Soytas and Sari, 2003).Unlike the current studies, this study employs the Ecological Footprint (EFP hereafter), as well as $\mathrm{CO}_{2}$ emissions, as indicators of environmental degradation. Furthermore, 
none of the previous studies put any attention to forecast the indicators of environmental deterioration. Therefore, this study employs the classical multiplicative decomposition method to predict EFP and $\mathrm{CO}_{2}$ in Turkey.

This study departs from previous studies in the following regards:

First, ecological footprint and carbon dioxide are both used to test the validity of the Environmental Kuznets Curve hypothesis in Turkey. Second, the article addresses the methodological limitations of previous studies by employing the approach of Narayan and Narayan (2010) which compares the long-run and short-run elasticities of per capita income (GDP). Third, the study employs classical multiplicative decomposition method to forecast the ecological footprint and carbon dioxide, which is to the best of my knowledge the only study employs this method of analysis to forecast the indicators of environmental deterioration.

\section{RESEARCH METHODOLOGY}

\section{A. MODEL SPECIFICATION AND DATA}

To investigate the relationship between economic growth and environmental pollution in Turkey this study uses the EFP, $\mathrm{CO}_{2}$ and per capita real income as a proxy for pollution and economic growth, respectively. The time series data about EFP is obtained from the (Global Footprint Network). The series on per capita real income (GDP), foreign direct investment (FDI) and energy consumption (EC) are obtained from the World Bank (world development indicators). All variables are used in natural logarithmic form in empirical analysis.

Many researchers have shown the limitation of traditional EKC that use the real GDP and its quadratic term to investigate the validity of EKC hypothesis (e.g., Narayan and Narayan, 2010; Sirag et al., 2018). Therefore, this study examines the relationship between per capita GDP and ecological footprint (EFP) in both long-run and short-run following the empirical testing procedures suggested by Narayan and Narayan (2010).

In addition, the study also will specify another model in which $\mathrm{CO}_{2}$ emissions is used as a measure of environmental pollution. In this method shortrun elasticity is compared to long-run elasticity to test whether the hypothesis is valid or not. If it turns out that long-run elasticity is smaller than short-run elasticity, then environmental quality is improved by the growth of per capita income (GDP) over time and the EKC does exist. According to the idea of Narayan and Narayan (2010) and based on the empirical work of Mrabet et al. (2017) our two models can be specified as follows:

$$
\ln E F P_{t}=\beta_{0}+\beta_{1} \ln G D P_{t}+\varepsilon_{t}
$$




$$
\operatorname{lnCO2} 2_{t}=\beta_{0}+\beta_{1} \operatorname{lnGDP} P_{t}+\varepsilon_{t}
$$

Where the EFP is the ecological footprint, GDP is the per capita real income, $\mathrm{CO}_{2}$ is carbon dioxide, $\beta_{1}$ is the long-run elasticity and $\varepsilon_{t}$ is the error term. The bivariate specification might not capture all the factors that contribute to environmental pollution so additional variables can be added to the modelsin the following manner:

$$
\begin{aligned}
& \ln E F P_{t}=\alpha_{0}+\alpha_{1} \ln G D P_{t}+\alpha_{2} \ln F D I_{t}+\alpha_{3} \ln E C_{t}+e_{t}
\end{aligned}
$$

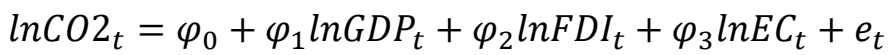

Where the FDI is foreign direct investment measured as a percentage of per capita real GDP and EC is the energy consumption and $\alpha_{1}, \alpha_{2}, \alpha_{3} \varphi_{1}, \varphi_{2}$, $\varphi_{3}$ are their long-run elasticities.

\section{B. METHOD OF ESTIMATION}

Most time series data are non-stationary in nature which result in misleading outcomes of regression analysis. To test for the stationarity properties of the variables this study uses the augmented Dickey-Fuller (1979) (ADF), Phillips and Perron (1988) (PP) tests. The null hypothesis of the ADF and PP tests indicate a unit root.

To test the validity of the Environmental Kuznets Hypothesis (EKC) this study utilizes the Autoregressive Distributed Lag (ARDL) model for the many advantages that distinguish it among other methods. First, this model does not required that all variable be integrated of order zero or I(0). Second, both shortrun and long-run models are estimated simultaneously. In addition, the ARDL method tends to perform better in a small sample size compared to multivariate analysis. To test the existence of cointegration relationships among the variables in model (1) and (2) the unrestricted error correction term (ECT) proposed by Pesaran et al. (2001) can be specified as follows:

$$
\begin{aligned}
\Delta \ln E F P_{t}=\delta_{0}+ & \delta_{1} \ln E F P_{t-1}+\delta_{2} \operatorname{lnGDP}_{t-1}+\sum_{i=1}^{q} \delta_{3} \Delta \ln E F P_{t-i} \\
& +\sum_{\substack{i=0 \\
p}}^{p} \delta_{4} \Delta \ln G D P_{t-i}+\theta E C T_{t-i} \\
& +\mu_{t}
\end{aligned}
$$




$$
\begin{aligned}
\Delta \operatorname{lnCO2} 2_{t}=\psi_{0} & +\psi_{1} \operatorname{lnCO} 2_{t-1}+\psi_{2} \ln G D P_{t-1}+\sum_{i=1}^{q} \psi_{3} \Delta \ln C O 2_{t-i} \\
& +\sum_{i=0}^{p} \psi_{4} \Delta \ln G D P_{t-i}+\theta E C T_{t-i} \\
& +\mu_{t}
\end{aligned}
$$

Where equations (5) and (6) are ARDL (q,p) models and the lag lengths are chosen according to Akaike Information Criterion (AIC). To test the existence of cointegration relationships among the variables in model (3) and (4) the unrestricted error correction term (ECT) proposed by Pesaran et al. (2001) can be specified as follows:

$$
\begin{aligned}
\Delta \ln E F P_{t}=\gamma_{0} & +\gamma_{1} \ln E F P_{t-1}+\gamma_{2} \ln G D P_{t-1}+\gamma_{3} \ln F D I_{t-1}+\gamma_{4} \ln E C_{t-1} \\
& +\sum_{i=1}^{m} \gamma_{5} \Delta \ln E F P_{t-i}+\sum_{i=0}^{n} \gamma_{6} \Delta \ln G D P_{t-i}+\sum_{i=0}^{n} \gamma_{7} \Delta \ln F D I_{t-i} \\
& +\sum_{i=0}^{n} \gamma_{8} \Delta \ln E C_{t-i}+\theta E C T_{t-i} \\
& +v_{t} \\
\operatorname{lnCO2}_{t}=\lambda_{0} & +\lambda_{1} \ln C O 2_{t-1}+\lambda_{2} \ln G D P_{t-1}+\lambda_{3} \ln F D I_{t-1}+\lambda_{4} \ln E C_{t-1} \\
& +\sum_{i=1}^{m} \lambda_{5} \Delta \ln C O 2_{t-i}+\sum_{i=0}^{n} \lambda_{6} \Delta \ln G D P_{t-i}+\sum_{i=0}^{n} \lambda_{7} \Delta \ln T O_{t-i} \\
& +\sum_{i=0}^{n} \lambda_{8} \Delta \ln E C_{t-i}+\theta E C T_{t-i} \\
& +v_{t}
\end{aligned}
$$

Where equations (7) and (8) are $\operatorname{ARDL}(\mathrm{q}, \mathrm{p}, \mathrm{m}, \mathrm{n})$ models and the lag lengths are chosen according to Akaike Information Criterion (AIC). The bound test for cointegration is conducted based on the joint null hypothesis of no cointegration $H_{0}: \delta_{1}=\delta_{2}=0$ and $H_{0}: \gamma_{1}=\gamma_{2}=\gamma_{3}=\gamma_{4}=0$ against the alternative of cointegration $H_{1}: \delta_{1} \neq \delta_{2} \neq 0$ and $H_{1}: \gamma_{1} \neq \gamma_{2} \neq \gamma_{3} \neq \gamma_{4} \neq 0$, for equations (5) and (7) -respectively. And $H_{0}: \psi_{1}=\psi_{2}=0$ and $H_{0}: \lambda_{1}=\lambda_{2}=$ $\lambda_{3}=\lambda_{4}=0$ against the alternative of cointegration $H_{1}: \psi_{1} \neq \psi_{2} \neq 0$ and $H_{1}: \lambda_{1} \neq \lambda_{2} \neq \lambda_{3} \neq \lambda_{4} \neq 0$, for equations (6) and (8), respectively. The Wald F-statistic is employed to examine the existence of cointegration relationship among the selected variables.

The F-statistic is compared with the lower and upper bounds critical values. If the F-statistic is greater than the upper critical bound, then the null hypothesis of no cointegration is rejected and thus cointegration does exist. If the F-statistic however, is less than the lower critical bound the null hypothesis 
cannot be rejected and, therefore, cointegration does not exist. If the cointegration relationship exists, then the error correction model (ECM) can be estimated. The ECM shows the short-run dynamics and the speed of adjustment to disequilibrium.

\section{RESULTS AND DISCUSSION}

In this part of the study, the plots of the variables for the possible existence of stationarity are examined. The results of Augmented Dickey-Fuller (ADF) and Phillips-Perron (PP)unit root tests in table (1) and figure (5) (a, b, c, d) in the appendix show the results for the possible existence of a unit root test at the level as well as first-difference. The results of ADF and PP are quite similar since none of the variables are integrated of the second order. Particularly, the ADF results show that EFP and $\mathrm{CO}_{2}$ series are stationary at level. Also, the same is true for the PP test results regarding the ecological footprint and carbon dioxide. The other series like per capita real GDP, foreign direct investment (FDI) and energy consumption (EC) are stationary at the first difference at $\% 1$ level of significance for both Augmented Dickey-Fuller and Phillips-Perron. After identifying the series order of stationarity, the second step is to apply the cointegration test to identify the long-run relationships among the variables.

Table 1: Unit root tests

\begin{tabular}{|c|c|c|c|c|}
\hline \multirow[t]{2}{*}{ Variables } & \multicolumn{2}{|c|}{ ADF } & \multicolumn{2}{|c|}{ PP } \\
\hline & $\mathrm{C}$ & C\&T & $\mathrm{C}$ & C\&T \\
\hline LnEFP $_{\text {it }}$ & $\begin{array}{l}-0.6278 \\
(-2.926)\end{array}$ & $\begin{array}{l}-5.5234^{\mathrm{a}} \\
(-3.508)\end{array}$ & $\begin{array}{c}-0.9117 \\
(-2.925169)\end{array}$ & $\begin{array}{c}-5.5159^{\mathrm{a}} \\
(-3.508508)\end{array}$ \\
\hline $\mathrm{LnCO}_{2 \mathrm{it}}$ & $\begin{array}{c}-1.9054 \\
(-2.925169)\end{array}$ & $\begin{array}{c}-3.2287^{c} \\
(-3.508508)\end{array}$ & $-2.0482(-2.925169)$ & $\begin{array}{c}-3.2472^{\mathrm{c}} \\
(-3.508508)\end{array}$ \\
\hline $\operatorname{LnGDP}_{\text {it }}$ & $\begin{array}{c}0.6492 \\
(-2.925169) \\
\end{array}$ & $\begin{array}{c}-1.7350 \\
(-3.508508)\end{array}$ & $\begin{array}{c}0.7053 \\
(-2.925169) \\
\end{array}$ & $\begin{array}{c}-1.8273 \\
(-3.508508)\end{array}$ \\
\hline LnFDI $_{\text {it }}$ & $\begin{array}{c}-1.1311 \\
(-2.926622)\end{array}$ & $\begin{array}{c}-3.9161^{\mathrm{b}} \\
(-3.508508)\end{array}$ & $\begin{array}{c}-1.5772 \\
(-2.925169)\end{array}$ & $\begin{array}{c}-3.8073^{\mathrm{b}} \\
(-3.508508)\end{array}$ \\
\hline $\operatorname{LnEC}_{i t}$ & $-2.7986^{\mathrm{c}}(-2.925169)$ & $\begin{array}{c}-0.1360 \\
(-3.508508)\end{array}$ & $\begin{array}{c}-2.5916 \\
(-2.925169)\end{array}$ & $\begin{array}{c}-0.4674 \\
(-3.508508)\end{array}$ \\
\hline DLnEFP $_{\text {it }}$ & $\begin{array}{c}-6.9944^{\mathrm{a}} \\
(-2.926622)\end{array}$ & $\begin{array}{c}-6.9163^{\mathrm{a}} \\
(-3.510740)\end{array}$ & $\begin{array}{c}-14.752^{\mathrm{a}} \\
(-2.926622)\end{array}$ & $\begin{array}{c}-15.539^{\mathrm{a}} \\
(-3.510740)\end{array}$ \\
\hline $\mathrm{DLnCO}_{2 \mathrm{it}}$ & $\begin{array}{c}-6.3240^{\mathrm{a}} \\
(-2.926622)\end{array}$ & $\begin{array}{c}-6.4228^{\mathrm{a}} \\
(-3.510740)\end{array}$ & $\begin{array}{c}-6.3281^{\mathrm{a}} \\
(-2.926622)\end{array}$ & $\begin{array}{c}-6.5463^{\mathrm{a}} \\
(-3.510740)\end{array}$ \\
\hline DLnGDP $_{\text {it }}$ & $\begin{array}{c}-6.53199^{\mathrm{a}} \\
(-2.926622)\end{array}$ & $\begin{array}{c}-6.6067^{\mathrm{a}} \\
(-3.510740)\end{array}$ & $-6.5326^{\mathrm{a}}(-2.926622)$ & $\begin{array}{c}-6.6045^{\mathrm{a}} \\
(-3.510740)\end{array}$ \\
\hline DLnFDI $_{\text {it }}$ & $\begin{array}{c}-9.7354^{\mathrm{a}} \\
(-2.926622)\end{array}$ & $\begin{array}{c}-9.6594^{\mathrm{a}} \\
(-3.510740)\end{array}$ & $\begin{array}{c}-10.2776^{\mathrm{a}} \\
(-2.926622)\end{array}$ & $\begin{array}{c}-10.264^{\mathrm{a}} \\
(-3.510740)\end{array}$ \\
\hline DLnEC $_{\text {it }}$ & $\begin{array}{c}-5.3804^{\mathrm{a}} \\
(-2.926622)\end{array}$ & $\begin{array}{c}-5.8573^{\mathrm{a}} \\
(-3.510740)\end{array}$ & $\begin{array}{c}-5.3387^{\mathrm{a}} \\
(-2.926622)\end{array}$ & $\begin{array}{c}-5.8586^{\mathrm{a}} \\
(-3.510740)\end{array}$ \\
\hline
\end{tabular}


Although the ARDL bound test for cointegration has several advantages, it has low power since it does not take into consideration the possibility of structural or regime shifts in the cointegrating vector (Gregory and Hansen, 1996; Hatemi-j, 2008). Table (2) presents the findings of unit root test with one structural break. Precisely, the results indicate that all the variables are nonstationary I(1). From the analysis of various unit root tests, the variables are found to be compatible with ARDL model.

Table 2: ADF unit root test with structural break

\begin{tabular}{|c|c|c|c|c|}
\hline \multirow[t]{2}{*}{ Variables } & \multicolumn{4}{|c|}{ ADF } \\
\hline & $\mathrm{C}$ & Break date & C\&T & Break date \\
\hline $\operatorname{LnEFP}_{\text {it }}$ & $\begin{array}{c}-1.810445(- \\
4.443649)\end{array}$ & 2002 & $\begin{array}{c}-5.910665^{\mathrm{a}}(- \\
4.859812)\end{array}$ & 1998 \\
\hline $\mathrm{LnCO}_{\text {it }}$ & $\begin{array}{c}-2.614590(- \\
4.443649)\end{array}$ & 2002 & $\begin{array}{c}-4.840363^{\mathrm{c}}(- \\
4.859812)\end{array}$ & 1984 \\
\hline $\operatorname{LnGDP}_{\text {it }}$ & $\begin{array}{c}-1.492486(- \\
4.443649)\end{array}$ & 2002 & $\begin{array}{c}-4.097208^{c}(- \\
4.859812)\end{array}$ & 2010 \\
\hline $\operatorname{LnFDI}_{\mathbf{i t}}$ & $\begin{array}{c}-2.990405(- \\
4.443649)\end{array}$ & 1987 & $\begin{array}{c}-4.264594(- \\
4.859812)\end{array}$ & 1987 \\
\hline $\operatorname{LnEC}_{\text {it }}$ & $\begin{array}{c}-3.600589(- \\
4.859812)\end{array}$ & 1982 & $\begin{array}{l}-2.989276(- \\
4.859812)\end{array}$ & 2015 \\
\hline DLnEFP $_{\text {it }}$ & $\begin{array}{c}-10.91857^{\mathrm{a}}(- \\
4.443649)\end{array}$ & 1993 & $\begin{array}{c}-10.54340^{\mathrm{a}}(- \\
4.859812)\end{array}$ & 1993 \\
\hline $\mathrm{DLnCO} 2_{\text {it }}$ & $\begin{array}{c}-6.676734^{\mathrm{a}}(- \\
4.443649)\end{array}$ & 1987 & $\begin{array}{c}-6.553104^{\mathrm{a}}(- \\
4.859812)\end{array}$ & 1987 \\
\hline DLnGDP $_{\text {it }}$ & $\begin{array}{c}-7.348009^{a}(- \\
4.443649)\end{array}$ & 2009 & $\begin{array}{c}-7.288775^{\mathrm{a}}(- \\
4.859812)\end{array}$ & 2009 \\
\hline DLnFDI $_{i t}$ & $\begin{array}{c}-10.23237^{a}(- \\
4.443649)\end{array}$ & 2001 & $\begin{array}{c}-9.744954^{\mathrm{a}}(- \\
4.859812)\end{array}$ & 1984 \\
\hline $\operatorname{DLnEC}_{i t}$ & $\begin{array}{c}-6.799315^{\mathrm{a}}(- \\
4.443649)\end{array}$ & 2014 & $\begin{array}{c}-6.931945^{\mathrm{a}}(- \\
4.859812)\end{array}$ & 2013 \\
\hline $\begin{array}{l}\text { Note: }{ }^{a}, b \text { de } \\
\text { trend. The } v\end{array}$ & $\begin{array}{l}\text { nt at } \% 1 \text { a } \\
\text { e the critice }\end{array}$ & $\begin{array}{l}\text { ctively. } \\
\text { \% level o }\end{array}$ & tercept, $C \& 1$ & itercept anc \\
\hline
\end{tabular}

In case cointegrations exist then it can be inferred that there is long-run relationship among the variables. In this study ARDL bound test to cointegration method is employed. Starting with the bound test to cointegration, table (3) shows that the model 1 has failed to pass the test, the F-statistic value (2.303824) is lower than the upper critical value (4.35), therefore only the short-run model can be estimated. However, the long-run and short-run model can be estimated for model 2 since the model has passed the F-statistic test of cointegration at $1 \%$ level of significance. It can be concluded that the cointegration test shows the existence of long-run relationships among the variables in model 2, so it will be the focus of the subsequent analysis. 
Table 3: Bound test for cointegration

\begin{tabular}{|c|c|c|c|}
\hline \multirow[t]{2}{*}{ The model } & \multirow[t]{2}{*}{ F-statistic } & \multicolumn{2}{|c|}{ Critical values } \\
\hline & & $\mathrm{I}(0)$ & $\mathrm{I}(1)$ \\
\hline $\operatorname{LnEFP}_{\mathrm{it}}=\mathbf{F}\left(\mathrm{LnGDP}_{\mathrm{it}}, \operatorname{LnFDI}_{\mathrm{it}}, \operatorname{LnEC}_{\mathrm{it}}\right)$ & 2.303824 & 3.23 & 4.35 \\
\hline $\operatorname{LnCO2}_{\text {it }}=\mathbf{F}\left(\operatorname{LnGDP}_{\text {it }}, \operatorname{LnFDI}_{\mathrm{it}}, \operatorname{LnEC}_{\mathrm{it}}\right)$ & 5.077470 & 3.23 & $4.35^{\mathrm{a}}$ \\
\hline
\end{tabular}

After confirming the existence of the long-run relationship to our models, we can now turn to estimate short-run and long run models. Since the bound test does not show cointegration evidence in the first model; only model 2 will be estimated. Table (4) shows the short-run estimates for model 1, it indicates that all the variables are significant in explaining the change in pollution. In particular, a $1 \%$ change in per capita real income and energy consumption will increase the pollution by $0.7354 \%$ and $1.2808 \%$ respectively. However, foreign direct investment has a negative impact on the pollution.

Table (5) demonstrates the ARDL results for model 2. It reveals that per capita real GDP is positive and significant in the long-run and negative and significant in the short-run. Moreover, the results also show that the short-run elasticity (0.741421) is smaller than the long-run elasticity (2.545893). This may indicate the absence of the EKC hypothesis. This conclusion is supported by figure (6) which reveals that pollution (EFP and $\mathrm{CO}_{2}$ ) is increasing with per capita real GDP. Nonetheless, the results also reveal the significance of per capita real GDP in explaining the change in $\mathrm{CO}_{2}$ in the short-run and long-run. It indicates that a1\% increase in per capita real GDP will lead to a positive change in $\mathrm{CO}_{2}$ by $0.74 \%$ and $2.54 \%$ in short-run and long-run respectively. The other variables are also found to be significant in the short-run and long-run. It reveals that the EC is the most pollutant, if it increases by $1 \%$ this will lead to an increase in $\mathrm{CO}_{2}$ by $1.613 \%$ in the short-run but in the long-run pollution caused by energy consumption will be decreasing by $-5.295 \%$. The results also show that more foreign direct investment will increase environmental pollution by $0.0041 \%$ and $0.0645 \%$ in the short-run and long-run respectively. 
Table 4: Short-run coefficients - model 1

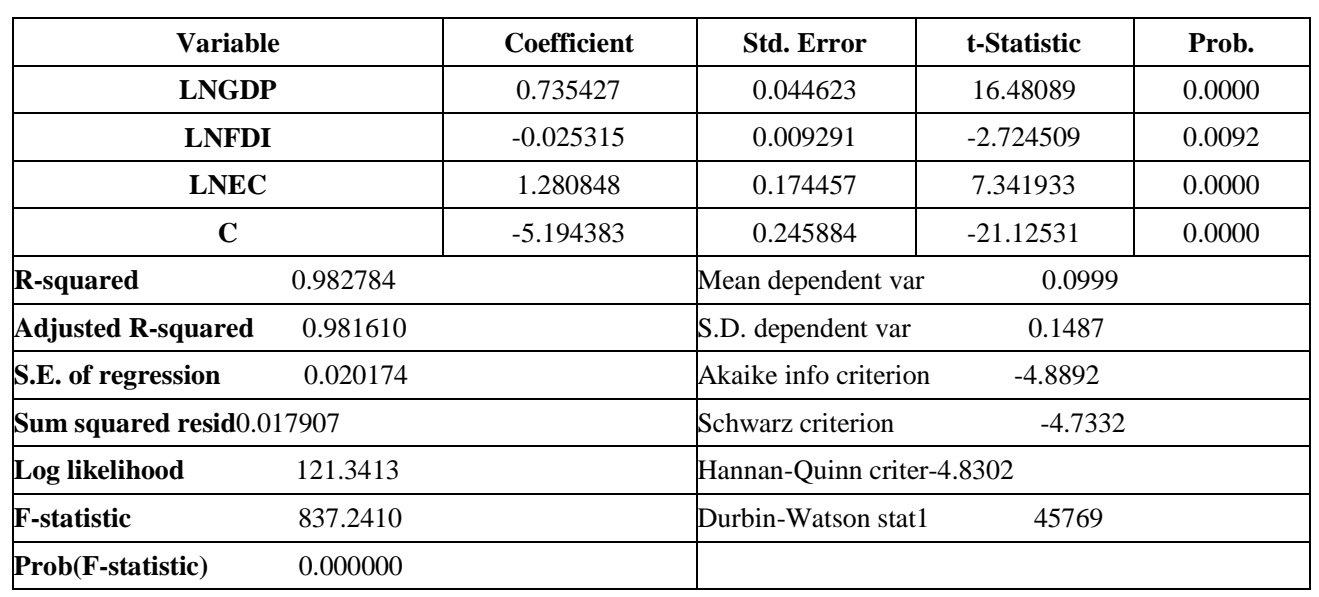

Table 5: ARDL results- model 2

\begin{tabular}{|l|l|l|l|c|}
\hline \multicolumn{5}{|c|}{ Long-run coefficients } \\
\hline Variable & Coefficient & Std. Error & t-Statistic & Prob. \\
\hline Constant & 5.651924 & 9.327309 & 0.605954 & 0.5481 \\
\hline LnGDP $_{\text {it }}$ & 2.545893 & 1.351896 & 1.883202 & 0.0673 \\
\hline LnFDI $_{\text {it }}$ & 0.064586 & 0.124439 & 0.519018 & 0.6068 \\
\hline LnEC $_{\text {it }}$ & -5.295756 & 7.367007 & -0.718848 & 0.4766 \\
\hline \multicolumn{5}{|l|}{ Short-run coefficients } \\
\hline DLnGDP $_{\text {it }}$ & 0.741421 & 0.101772 & 7.285147 & 0.0000 \\
\hline DLnFDI $_{\text {it }}$ & 0.004108 & 0.006505 & 0.631485 & 0.5315 \\
\hline DLnEC $_{\text {it }}$ & 1.613494 & 0.282023 & 5.721150 & 0.0000 \\
\hline ECT $^{\mid}$ & -0.063599 & 0.052334 & -1.215264 & 0.2318 \\
\hline
\end{tabular}

The ARDL model is further evaluated by the diagnostic tests such as serial correlation, heteroskedasticity and histogram normality test. Table 6 illustrates the findings of the Breusch-Godfrey Serial Correlation LM Test. The prob value is $(0.7880)$, so, the model is stable since the null hypothesis of no serial correlation cannot be rejected. In addition, table 7 presents theheteroskedasticity test: Breusch-Pagan-Godfrey. It indicates that the model is not suffering from the heteroskedasticity, since the null hypothesis of no heteroskedasticity cannot be rejected, the p-value is 0.8173 . Moreover, the ARDL model is also evaluated by the Histogram Normality Test. Figure 3 shows the findings of the normality test. It indicates that the model follows the normality since the probability value of the Jarque-Beta is 0.3143 and P-value is 0.314. Furthermore, Ramsey-reset test is performed. Table 8 clearly show that 
the ARDL model is free from any specification error since the null hypothesis of no regression specification error cannot be rejected.

Table 6: Breusch-Godfrey Serial Correlation LM Test:

\begin{tabular}{|l|l|l|l|}
\hline F-statistic & 0.239813 & Prob. F(2,36) & 0.7880 \\
\hline Obs*R-squared & 0.604799 & Prob. Chi-Square(2) & 0.7390 \\
\hline
\end{tabular}

Table 7: Heteroskedasticity Test: Breusch-Pagan-Godfrey

\begin{tabular}{|l|c|l|c|}
\hline F-statistic & 0.515281 & Prob. F(7,38) & 0.8173 \\
\hline Obs*R-squared & 3.987806 & Prob. Chi-Square(7) & 0.7812 \\
\hline Scaled explained SS & 2.007576 & Prob. Chi-Square(7) & 0.9594 \\
\hline
\end{tabular}

Figure 4: Histogram Normality Test

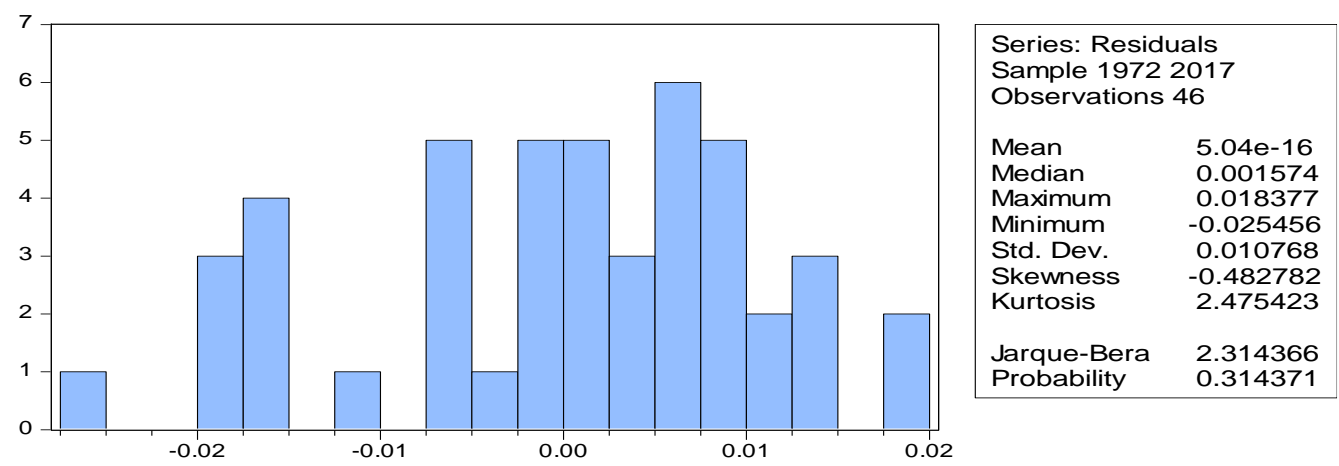


Table 8: Ramsey RESET Test

\begin{tabular}{|c|c|c|c|}
\hline \multicolumn{4}{|c|}{ Specification: LNEFP LNGDP LNFDI LNEC C } \\
\hline \multicolumn{4}{|c|}{ Omitted Variables: Squares of fitted values } \\
\hline & Value & $\mathrm{df}$ & Probability \\
\hline t-statistic & 0.524446 & 43 & 0.6027 \\
\hline F-statistic & 0.275044 & $(1,43)$ & 0.6027 \\
\hline Likelihood ratio & 0.306048 & 1 & 0.5801 \\
\hline \multicolumn{4}{|l|}{ F-test summary: } \\
\hline & Sum of Sq. & $\mathrm{df}$ & Mean Squares \\
\hline Test SSR & 0.000464 & 1 & 0.000464 \\
\hline Restricted SSR & 0.072961 & 44 & 0.001658 \\
\hline Unrestricted SSR & 0.072497 & 43 & 0.001686 \\
\hline \multicolumn{4}{|l|}{ LR test summary: } \\
\hline & Value & $\mathrm{df}$ & \\
\hline Restricted LogL & 87.62764 & 44 & \\
\hline Unrestricted LogL & 87.78067 & 43 & \\
\hline
\end{tabular}

To sum up, the results present an evidence against the EKC hypothesis in the case of Turkey indicating that the growth of per capita real GDP will cause further damage to the environment. In addition, the stability of models is assessed using the CUSUM and CUSUMSQ test as suggested by Pesaran. ${ }^{\dagger}$ Figure (7) and (8) present the findings of CUSUM and CUSUMSQ for model 1and model 2 respectively. The models have passed the test indicating the stability of the estimated parameters.

Furthermore, the study employed the classical multiplicative decomposition method to forecast pollution in Turkey for the next three years. Figure (9) shows that both ecological footprint and carbon dioxide will be increasing. An important result comes out from this study is that the EKC hypothesis is not valid in the case of Turkey. The results of the non-existence of the EKC hypothesis agree with other studies, (see, for example, Al-Mulaliet al., 2015; Lachehebet al., 2015; Siraget al., 2018).

However, the findings contradict many existing studies. The findings are in contrary to those of Awad (2019) who found support for the EKC hypothesis in selected African countries using panel data analysis. His results may be attributed to the heterogeneity bias and use the conventional EKC approach and the $\mathrm{CO}_{2}$ as a measure for environmental quality. Another study by Ike et al. (2020) confirmed the EKC hypothesis only in countries with high $\mathrm{CO}_{2}$ emission, while the opposite was not true for low $\mathrm{CO}_{2}$ emitting countries. Unlike Ike et al.

\footnotetext{
${ }^{\dagger}$ CUSUM and CUSUM of Squares refer to Cumulative sum and cumulative sum of squares, respectively.
} 
(2020), our study uses the EFP which is more comprehensive measure to the environment.

Likewise, Sarkodie and Ozturk (2020) used the $\mathrm{CO}_{2}$ emissions as indicator for environmental degradation and found evidence supports the existence of the EKC hypothesis in Kenya. Although Charfeddine and Mrabet (2017) used the EFP as an indicator for the environment, but they relied on the conventional testing of the EKC. Their results have validated the existence of the EKC only in the sample of oil-exporting countries.

\section{CONCLUSION AND POLICY RECOMMENDATIONS}

Since the early 1970s, specifically after the United Nations Conference on the Human-Environment in 1972, the relationship between production activities and environmental concerns has been studied by different methods in different disciplines. This is because the environment is of vital importance for human life, and they are confronted with serious environmental problems.

This study examined the impact of economic growth on environmental pollution in Turkey. The EFP and $\mathrm{CO}_{2}$ are used as measures of environmental pollution and per capita real GDP as a measure for economic growth. The study relied on the available time-series data for the period from 1970 to 2017. Since the macroeconomic data are non-stationary and are subject to unit root, ADF and PP unit root tests were applied to determine the series order of stationarity.

Furthermore, after none of the variables were found to be integrated of the second order, the cointegration test of Pesaran et al. (2001) was performed to verify the existence of a long-run relations among the variables. The ARDL approach for cointegration was used to estimate the long-run and short-run models. In addition, the classical additive decomposition method was employed to forecast pollution in Turkey for the next three years.

The results indicated that the per capita real income (GDP) has a positive significant effect on the environmental pollution $\left(\mathrm{CO}_{2}\right)$ in the long-run and short-run. When the long-run and short-run elasticities were compared the EKC hypothesis was found not to exist. The other explanatory variables were also found to be significant in explaining pollution.

The results reveal that more foreign direct investment (FDI) increases pollution in Turkey as well as energy consumption in short run. Based on the results obtained by this study, an important implication can be drawn. First, the absence of the EKC hypothesis in Turkey. Second, the environmental policies aim to improve the environmental quality are less effective. Third, more foreign direct investment can increase environmental pollution. Fourth, the pollution that caused by energy consumption will be decreasing in the long run. 
The study can therefore draw the following recommendations for policy and future research: first, robust and effective environmental policies should be strictly implemented and closely monitored to reduce environmental pollution and ensure the reservation of resources for future generations. Second, more policies to manage foreign direct investment are also needed since advanced and environmentally friendly technology is used, and that will eventually reduce pollution. Third, since the energy consumption can contribute to pollution, there will be a need to concentrate more on clean and renewable energy which may have less environmental damage. Fifth, for future research, more studies are needed to investigate the relationship between economic growth and environmental pollution, especially in Turkey to help policymakers and investors design effective policies and keep the pollution in check.

\section{REFERENCES}

Acaravci, A., and Akalin, G. (2017). Environment-economic growth nexus: a comparative analysis of developed and developing countries. International Journal of Energy Economics and Policy, 7(5), 34-43.

Adu, D. T., and Denkyirah, E. K. (2018). Economic growth and environmental pollution in West Africa: Testing the Environmental Kuznets Curve hypothesis. Kasetsart Journal of Social Sciences.

Akbostanc1, E., Türüt-Aşık, S., and Tunç, G. İ. (2009). The relationship between income and environment in Turkey: is there an environmental Kuznets curve? Energy policy, 37(3), 861-867.

Ali, W., Abdullah, A., and Azam, M. (2017). Re-visiting the environmental Kuznets curve hypothesis for Malaysia: fresh evidence from ARDL bounds testing approach. Renewable and sustainable energy reviews, 77, 990-1000.

Al-Mulali, U., Ozturk, I., and Solarin, S. A. (2016). Investigating the environmental Kuznets curve hypothesis in seven regions: The role of renewable energy. Ecological indicators, 67, 267-282.

Al-Mulali, U., Saboori, B., and Ozturk, I. (2015). Investigating the environmental Kuznets curve hypothesis in Vietnam. Energy Policy, 76, 123-131.

Altinay, G., and Karagol, E. (2004). Structural break, unit root, and the causality between energy consumption and GDP in Turkey. Energy economics, 26(6), 985-994. 
Altıntaş, H., and Kassouri, Y. (2020). Is the environmental Kuznets Curve in Europe related to the per-capita ecological footprint or $\mathrm{CO} 2$ emissions? Ecological Indicators, 113, 106187.

Apergis, N. (2016). Environmental Kuznets curves: New evidence on both panel and country-level CO2 emissions. Energy Economics, 54, 263-271.

Aslan, A., Destek, M. A., and Okumus, I. (2018). Bootstrap rolling window estimation approach to analysis of the Environment Kuznets Curve hypothesis: evidence from the USA. Environmental Science and Pollution Research, 25(3), 2402-2408.

Awad, A. (2019). Does economic integration damage or benefit the environment? Africa's experience. Energy Policy, 132, 991-999.

Ben Jebli, M., Ben Youssef, S., and Ozturk, I. (2015). The role of renewable energy consumption and trade: Environmental Kuznets curve analysis for sub-Saharan Africa countries. African Development Review, 27(3), 288-300.

Bölük, G., and Mert, M. (2015). The renewable energy, growth and environmental Kuznets curve in Turkey: an ARDL approach. Renewable and Sustainable Energy Reviews, 52, 587-595.

CANBAY, Ş. (2019). Türkiye'de iktisadi büyüme ile yenilenebilir enerji tüketiminin çevre kirliliği üzerindeki etkileri. MaliyeDergisi, 176, 140151.

Charfeddine, L., and Mrabet, Z. (2017). The impact of economic development and social-political factors on ecological footprint: A panel data analysis for 15 MENA countries. Renewable and Sustainable Energy Reviews, 76, 138-154.

Diao, X. D., Zeng, S. X., Tam, C. M., and Tam, V. W. (2009). EKC analysis for studying economic growth and environmental quality: a case study in China. Journal of Cleaner Production, 17(5), 541-548.

Dickey, David. A. and Wayne Fuller. A. (1979). Distribution of the estimators for autoregressive Time Series with a Unit Root. Journal of the American Statistical Association, 74(366), 427-431.

Dogan, E., Ulucak, R., Kocak, E., and Isik, C. (2020). The use of ecological footprint in estimating the Environmental Kuznets Curve hypothesis for BRICST by considering cross-section dependence and heterogeneity. Science of the Total Environment, 138063.

Fiala, N. (2008). Measuring sustainability: Why the ecological footprint is bad economics and bad environmental science. Ecological economics, 67(4), 519-525. 
Furuoka, F. (2015). Financial development and energy consumption: Evidence from a heterogeneous panel of Asian countries. Renewable and Sustainable Energy Reviews, 52, 430-444.

Erdal, G., Erdal, H., and Esengün, K. (2008). The causality between energy consumption and economic growth in Turkey. Energy Policy, 36(10), 3838-3842.

Gregory, A. W., and Hansen, B. E. (1996). Residual-based tests for cointegration in models with regime shifts. Journal of econometrics, 70(1), 99-126.

Global Footprint Network. Ecological Footprint. 28.12.2020:https://www.footprintnetwork.org/

Grossman, G. M., and Krueger, A. B. (1991). Environmental impacts of a North American free trade agreement (No. w3914). National Bureau of economic research.

Halicioglu, F. (2009). An econometric study of CO2 emissions, energy consumption, income and foreign trade in Turkey. Energy policy, 37(3), 1156-1164.

Hatemi-j, A. (2008). Tests for cointegration with two unknown regime shifts with an application to financial market integration. Empirical Economics, 35(3), 497-505.

He, J., and Richard, P. (2010). Environmental Kuznets curve for CO2 in Canada. Ecological Economics, 69(5), 1083-1093.

Jalil, A., and Mahmud, S. F. (2009). Environment Kuznets curve for CO2 emissions: a cointegration analysis for China. Energy policy, 37(12), 5167-5172.

Jobert, T., and Karanfil, F. (2007). Sectoral energy consumption by source and economic growth in Turkey. Energy policy,35(11), 54475456.

Johansen, S., and Juselius, K. (1994). Identification of the long-run and the short-run structure an application to the ISLM model. Journal of Econometrics, 63(1), 7-36.

Johansen, S. (1988). Statistical analysis of cointegration vectors. Journal of economic dynamics and control, 12(2-3), 231-254.

Ike, G. N., Usman, O., and Sarkodie, S. A. (2020). Testing the role of oil production in the environmental Kuznets curve of oil producing countries: New insights from Method of Moments Quantile Regression. Science of the Total Environment, 711, 135208. 
Iwata, H., Okada, K., and Samreth, S. (2010). Empirical study on the environmental Kuznets curve for $\mathrm{CO} 2$ in France: the role of nuclear energy. Energy Policy, 38(8), 4057-4063.

Katircioğlu, S. T., and Taşpinar, N. (2017). Testing the moderating role of financial development in an environmental Kuznets curve: empirical evidence from Turkey. Renewable and Sustainable Energy Reviews, 68, 572-586.

Kuznets, S. (1955). Economic growth and income inequality. The American economic review, 45(1), 1-28.

Kwiatkowski, D., Phillips, P. C., Schmidt, P., and Shin, Y. (1992). Testing the null hypothesis of stationarity against the alternative of a unit root. Journal of econometrics, 54(1-3), 159-178.

Lacheheb, M., Rahim, A. A., and Sirag, A. (2015). Economic growth and carbon dioxide emissions: Investigating the environmental Kuznets curve hypothesis in Algeria. International Journal of Energy Economics and Policy, 5(4), 1125-1132.

Lieb, C. M. (2003). The environmental Kuznets curve: a survey of the empirical evidence and of possible causes (No. 391). Discussion paper series.

Li, T., Wang, Y., and Zhao, D. (2016). Environmental Kuznets curve in China: new evidence from dynamic panel analysis. Energy Policy, 91, 138-147.

Lopez, R., Islam, A. (2008), Trade and the environment. The Princeton Encyclopedia of the World Economy, 24, 22-23.

Lise, W. (2006). Decomposition of CO2 emissions over 1980-2003 in Turkey. Energy Policy, 34(14), 1841-1852.

Lise, W., and Van Montfort, K. (2007). Energy consumption and GDP in Turkey: Is there a co-integration relationship? Energy economics, 29(6), 1166-1178.

Moutinho, V., Varum, C., and Madaleno, M. (2017). How economic growth affects emissions? an investigation of the environmental Kuznets curve (EKC) in Portuguese and Spanish economic activity sectors. Research@ ua, $8,49-49$.

Mrabet, Z., AlSamara, M., and Jarallah, S. H. (2017). The impact of economic development on environmental degradation in Qatar. Environmental and ecological statistics, 24(1), 7-38.

Narayan, P. K., and Narayan, S. (2010). Carbon dioxide emissions and economic growth: Panel data evidence from developing countries. Energy policy, 38(1), 661-666. 
Özokcu, S., and Özdemir, Ö. (2017). Economic growth, energy, and environmental Kuznets curve. Renewable and Sustainable Energy Reviews, 72, 639-647.

Pata, U. K. (2018). Renewable energy consumption, urbanization, financial development, income and $\mathrm{CO}_{2}$ emissions in Turkey: testing EKC hypothesis with structural breaks. Journal of Cleaner Production, 187, 770-779.

Perron, P. (1997). Further evidence on breaking trend functions in macroeconomic variables. Journal of econometrics, 80(2), 355-385.

Pesaran, M. H., Shin, Y., and Smith, R. J. (2001). Bounds testing approaches to the analysis of level relationships. Journal of applied econometrics, 16(3), 289-326.

Phillips, P. C., and Perron, P. (1988). Testing for a unit root in time series regression. Biometrika, 75(2), 335-346.

Rafindadi, A. A. (2016). Revisiting the concept of environmental Kuznets curve in period of energy disaster and deteriorating income: Empirical evidence from Japan. Energy Policy, 94, 274-284.

Raza, S. A., Shah, N., and Khan, K. A. (2020). Residential energy environmental Kuznets curve in emerging economies: the role of economic growth, renewable energy consumption, and financial development. Environmental Science and Pollution Research, 27(5), 5620-5629.

Saboori, B., Sulaiman, J., and Mohd, S. (2016). Environmental Kuznets curve and energy consumption in Malaysia: A cointegration approach. Energy Sources, Part B: Economics, Planning, and Policy, 11(9), 861-867.

Salahuddin, M., Alam, K., and Ozturk, I. (2016). The effects of Internet usage and economic growth on $\mathrm{CO} 2$ emissions in OECD countries: A panel investigation. Renewable and Sustainable Energy Reviews, 62, 12261235 .

Sarkodie, S. A., and Ozturk, I. (2020). Investigating the environmental Kuznets curve hypothesis in Kenya: a multivariate analysis. Renewable and Sustainable Energy Reviews, 117, 109481.

Say, N. P., and Yücel, M. (2006). Energy consumption and CO2 emissions in Turkey: Empirical analysis and future projection based on an economic growth. Energy policy, 34(18), 3870-3876.

Shahbaz, M., Solarin, S. A., Sbia, R., and Bibi, S. (2015). Does energy intensity contribute to $\mathrm{CO} 2$ emissions? A trivariate analysis in selected African countries. Ecological indicators, 50, 215-224. 
Shahbaz, M., Nasir, M. A., and Roubaud, D. (2018). Environmental degradation in France: the effects of FDI, financial development, and energy innovations. Energy Economics, 74, 843-857.

Shahbaz, M., Khraief, N., Uddin, G. S., and Ozturk, I. (2014). Environmental Kuznets curve in an open economy: a bounds testing and causality analysis for Tunisia. Renewable and Sustainable Energy Reviews, 34, 325-336.

Sirag, A., Matemilola, B. T., Law, S. H., and Bany-Ariffin, A. N. (2018). Does environmental Kuznets curve hypothesis exist? Evidence from dynamic panel threshold. Journal of environmental economics and policy, 7(2), 145-165.

Soytas, U., Sari, R., and Ozdemir, O. (2001). Energy consumption and GDP relation in Turkey: a cointegration and vector error correction analysis. Economies and business in transition: facilitating competitiveness and change in the global environment proceedings, 1 , 838-844.

Soytas, U., and Sari, R. (2009). Energy consumption, economic growth, and carbon emissions: challenges faced by an EU candidate member. Ecological economics, 68(6), 1667-1675.

Soytas, U., and Sari, R. (2003). Energy consumption and GDP: causality relationship in G-7 countries and emerging markets. Energy economics, 25(1), 33-37.

Solarin, S. A., and Bello, M. O. (2018). Persistence of policy shocks to an environmental degradation index: the case of ecological footprint in 128 developed and developing countries. Ecological indicators, 89, 35-44.

Stern, D. I. (2004). The rise and fall of the environmental Kuznets curve. World development, 32(8), 1419-1439.

Tao, S., Zheng, T., and Lianjun, T. (2008). An empirical test of the environmental Kuznets curve in China: a panel cointegration approach. China Economic Review, 19(3), 381-392.

The republic of Turkey: Eleventh Development Plan, 2019-2023: https://www.sbb.gov.tr/wpcontent/uploads/2020/03/On BirinciPLan ingilizce SonBaski.pdf

Tiwari, A. K., Shahbaz, M., and Hye, Q. M. A. (2013). The environmental Kuznets curve and the role of coal consumption in India: cointegration and causality analysis in an open economy. Renewable and Sustainable Energy Reviews, 18, 519-527. 
Tutulmaz, O. (2015). Environmental Kuznets curve time series application for Turkey: why controversial results exist for similar models? Renewable and Sustainable Energy Reviews, 50, 73-81.

Uddin, G. A., Salahuddin, M., Alam, K., and Gow, J. (2017). Ecological footprint and real income: Panel data evidence from the 27 highest emitting countries. Ecological Indicators, 77, 166-175.

Ulucak, R., and Bilgili, F. (2018). A reinvestigation of EKC model by ecological footprint measurement for high-, middle- and low-income countries. Journal of cleaner production, 188, 144-157.

Ulucak, R., and Lin, D. (2017). Persistence of policy shocks to Ecological Footprint of the USA. Ecological Indicators, 80, 337-343.

United Nations. Paris Agreement: https://www.un.org/en/

World Bank (world development indicators. 20.12.2020: https://databank.worldbank.org/source/world-development-indicators).

Yilanci, V., and Ozgur, O. (2019). Testing the environmental Kuznets curve for G7 countries: evidence from a bootstrap panel causality test in rolling windows. Environmental Science and Pollution Research,26(24), 24795-24805 


\section{APPENDIX}

Figure 3. Stationarity of the series

(a)

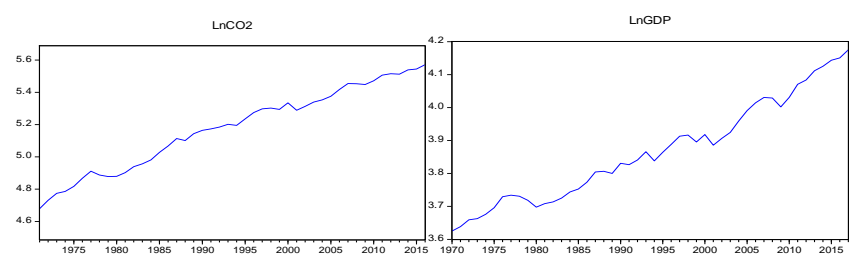

(c)

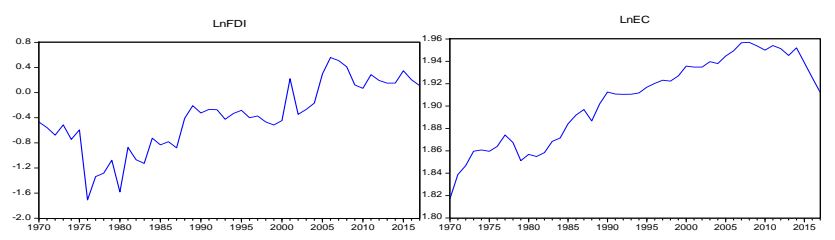

(b)

(d)
Figure 4. Ecological footprint, $\mathrm{CO}_{2}$ and per capita GDP
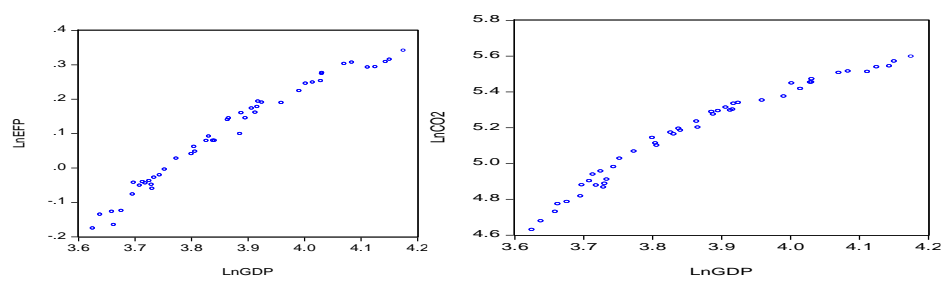
Figure 5. CUSUM and CUSUM of Squares test - model 1

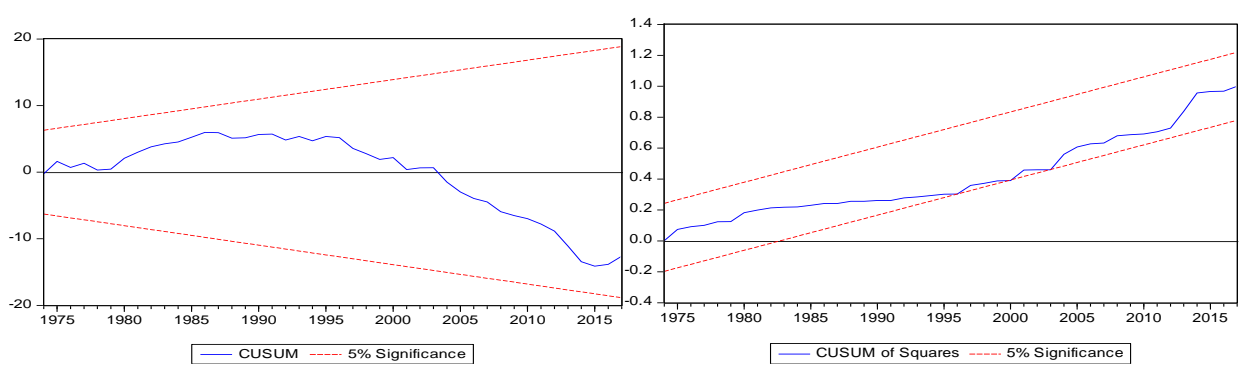

Figure 6. CUSUM and CUSUM of Squares test - model 2

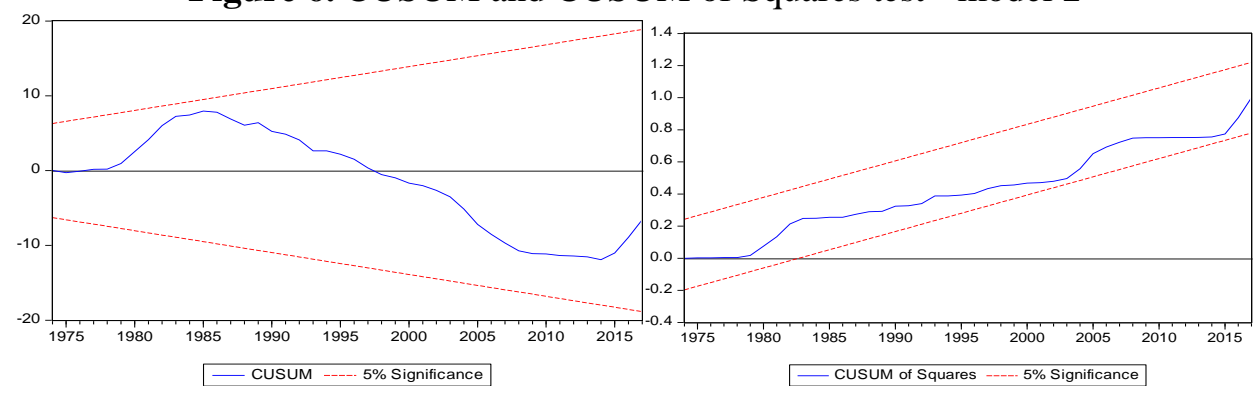

Figure 7. Classical additive decomposition method of Forecast (EFP CO2)

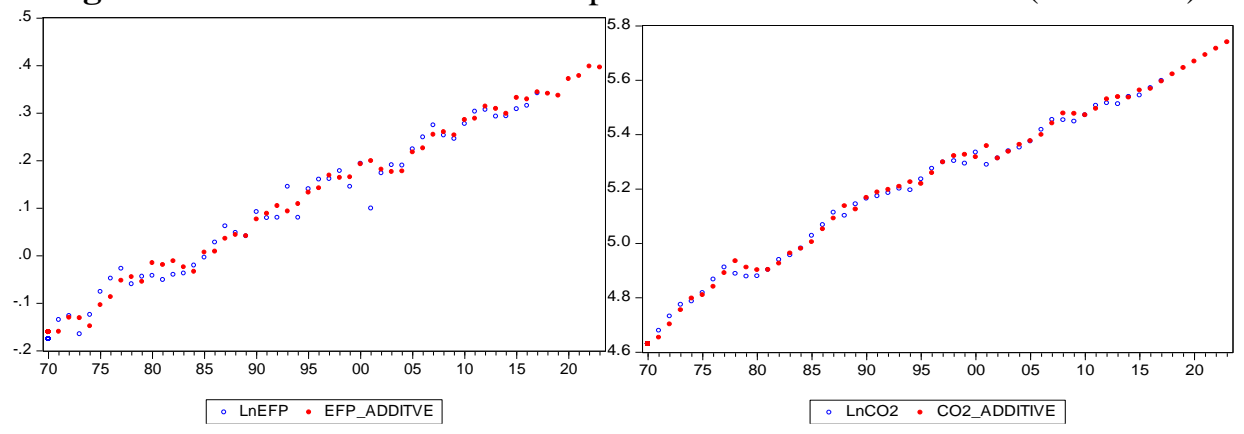

